\title{
Literatura e afrodescendência no Brasil: antologia crítica Eduardo de Assis Duarte e Maria Nazareth Soares Fonseca (orgs.) Belo Horizonte, UFMG, 2011 \\ Maria Carolina de Godoy ${ }^{1}$
}

O lançamento da coleção Literatura e afrodescendência no Brasil: antologia crítica (2011), organizada pelo professor Eduardo de Assis Duarte e Maria Nazareth Soares Fonseca (participante do volume 4), significa o marco do reconhecimento de um espaço, na crítica e na historiografia literárias, dedicado às obras da literatura afro-brasileira. Dividida em quatro livros, a coleção traz informações sobre os autores afro-brasileiros distribuídos por épocas: autores nascidos antes de 1930 (precursores), entre 1930 e 1940 (consolidação) e na segunda metade do século XX (contemporaneidade); o quarto volume é dedicado a ensaios críticos.

Os verbetes mostram dados relativos à vida pessoal e pública dos cem escritores e escritoras, uma vez que essas informações mesclam-se tanto à temática de suas obras quanto à intensa atividade acadêmica e política para o estabelecimento do espaço da voz negra na sociedade brasileira. Há textos críticos, referências bibliográficas para pesquisa, entrevistas e excertos de obras de diferentes gêneros - romance, conto, crônica, ensaios e poesia -, sendo possível identificar a escolha de mais de um gênero pelos autores, que, em sua maioria, iniciaram as produções nos Cadernos negros, publicação anual de autores afro-brasileiros que reúne prosa e poesia desde 1978, quando surgiu em São Paulo.

Nomes conhecidos da tradição, como Machado de Assis, Lima Barreto e Cruz e Sousa, dividem espaço, na coletânea, com aqueles apagados da historiografia tradicionalmente estudada nos currículos escolares: Luiz Gama, Domingos Caldas Barbosa, Maria Firmina dos Reis, Abdias Nascimento e Solano Trindade, apenas para mencionar os mais antigos. A literatura infantojuvenil é ressaltada nos nomes de Joel Rufino dos Santos, Heloisa Pires Lima, Cidinha da Silva, Rogério Andrade Barbosa e Júlio Emílio Braz. As autoras também são postas em evidência: Conceição Evaristo, Geni Guimarães, Miriam Alves, Esmeralda Ribeiro, entre outras.

Em artigo que abre o primeiro volume, intitulado "Entre Orfeu e Exu, a afrodescendência toma a palavra", Eduardo de Assis Duarte menciona

\footnotetext{
${ }^{1}$ Doutora em Estudos Literários e professora adjunta do Departamento de Letras Vernáculas e Clássicas da Universidade Estadual de Londrina (UEL), Londrina, Paraná, Brasil. Pesquisadora associada do Programa Avançado de Cultura Contemporânea da Universidade Federal do Rio de Janeiro (UFRJ).E-mail mcdegodoy@uol.com.br
} 
os estudos e ensaios críticos sobre os elementos de uma africanidade ou afro-brasilidade na produção literária a fim de destacar a importância desses trabalhos para a elaboração da antologia. Para compor a coleção, um dos critérios de escolha dos autores vivos foi, segundo o organizador, a concordância da denominação de literatura afro-brasileira que "apresenta temas, linguagem e, sobretudo, pontos de vista marcados pelo pertencimento étnico e pelo propósito de construir um texto afro-identificado" (Duarte, 2011a, p. 37).

Preservar essas características, ao organizar a coletânea, significa conduzir o olhar analítico para essa produção desprendido de critérios tradicionais de abordagem artística que consideram, como única forma de estudo literário, a análise imanente do texto. Compreende-se que, ao abordar uma literatura que remete a outros pressupostos de representação artística inscritos em torno da ou além das especificidades linguísticas, ou seja, que leva em consideração um estudo mais amplo quanto às representações discursivas inscritas no texto e ao seu redor, a análise imanente tende a ser o ponto de partida para os estudos dessas obras e não o único possível para considerá-las literárias ou não. Nas palavras de Antoine Compagnon:

A literatura, ou o estudo literário, está sempre imprensada entre duas abordagens irredutíveis: uma abordagem histórica, no sentido amplo (o texto como documento), e uma abordagem lingüística (o texto como fato da língua, a literatura como arte da linguagem) (Compagnon, 2003, p. 30).

A revisão do cânone está pressuposta ao se abrirem novas perspectivas e olhares para as produções literárias provenientes de grupos capazes de integrar todas as artes, além da literária, em torno de posicionamentos que pretendem promover não só mudanças sociais profundas, mas também revisões do modo de abordagem da arte literária. Ao propor a construção do conceito de literatura afro-brasileira, Eduardo de Assis Duarte conclui seu ensaio no quarto volume da coleção:

Uma literatura empenhada, sim, mas num projeto suplementar (no sentido derridiano) ao da literatura brasileira canônica: o de edificar uma escritura que seja não apenas a expressão dos afrodescendentes enquanto agentes de cultura e de arte, mas que aponte o etnocentrismo que os exclui do mundo das letras e da própria civilização. Daí seu caráter muitas vezes marginal, porque fundado na diferença, que questiona e abala a trajetória progressiva e linear de nossa história literária (Duarte, 2011b, p. 400). 
Visando à construção da história literária e à ampliação do estudo crítico das obras de autoras e autores negros e sua divulgação em todos os setores da educação, uma vez que a Lei $n^{\circ} 10.639 / 2003$ determina o ensino de cultura afro nas escolas, a coleção Literatura e afrodescendência no Brasil (2011) é contribuição ímpar às pesquisas futuras.

\section{Referências}

COMPAGNON, Antoine (2003). O demônio da teoria: literatura e senso comum. Trad. Cleonice Paes Barreto Mourão e Consuelo Fortes Santiago. Belo Horizonte: UFMG.

DUARTE, Eduardo de Assis (2011a). Entre Orfeu e Exu, a afrodescendência toma a palavra. In: (org.). Literatura e afrodescendência no Brasil: antologia crítica. v. 1 (Precursores). Belo Horizonte: Editora UFMG.

(2011b). Por um conceito de literatura afro-brasileira. In: Literatura e afrodescendência no Brasil: antologia crítica. v. 4 (História, teoria, polêmica). Belo Horizonte: Editora UFMG.

Recebido em dezembro de 2012.

Aprovado em janeiro de 2013. 